\title{
Reading Out the Establishment Clause
}

Securing Religious Liberty: Principles for Judicial Interpretation of the Religion Clauses. By Jesse H. Choper. Chicago: The University of Chicago Press, 1995. Pp. xiii, 190. \$24.95.

At a time when the role that religion should play in government is under increasing scrutiny in each of the three branches of the federal government, Jesse H. Choper's Securing Religious Liberty endeavors to bring coherence to the jurisprudence concerning the Free Exercise and Establishment Clauses of the First Amendment. Choper, the former Dean of the University of California at Berkeley School of Law, is not new to this area, having written numerous articles on various aspects of the Religion Clauses. ${ }^{2}$ In his latest work, Choper endeavors to articulate a "comprehensive thesis for adjudication of all significant issues that arise under the Religion Clauses" (p. 1). His scheme consists of four principles: two for the Free Exercise Clause and two for the Establishment Clause. Each pair of principles is accompanied by a corresponding, clause-specific definition of religion.

Though Choper exposes many inconsistencies in the existing jurisprudence, he fails to articulate a particular vision of the relationship between government and religion. He sees himself as taking a moderate position requiring sacrifices by those on both sides of the debate. Yet Choper's effort to bridge this divide

* Earl Warren Professor of Public Law, University of California, Berkeley.

1. See, e.g., Rosenberger v. University of Va., 115 S. Ct. 2510 (1995) (holding that state university's permitting school property to be used for presentation of all views except those addressing issues from religious standpoint not to be required by Establishment Clause and, in fact, to be prohibited viewpoint discrimination in violation of First Amendment); Board of Education v. Grumet, 114 S. Ct. 2481 (1994) (finding unconstitutional statute creating special school district in village incorporated to exclude all but practitioners, as violation of Establishment Clause); 8 S.J. Res. 6, 104th Cong., 1st Sess. (1995) (proposing constitutional amendment regarding school prayer), H.R.J. Res. 94, 104th Cong., 1st Sess. (1995) (same); Remarks at James Madison High School in Vienna, Virginia, 31 WeEkLY CoMP. PRES. DoC. 1220 (July 12, 1995) (discussing Religious Freedom Restoration Act, school prayer, and advocating what Choper describes as "neutrality" approach to religion in public schools); Memorandum on Religious Expression in Public Schools, 31 WEEKLY COMP. PRES. DOC. 1227 (July 12, 1995) (advocating neutrality approach to religion in public schools, including constitutionality of voluntary prayer and released time programs, as well as equal access to school facilities for religious student groups).

2. See, e.g., Jesse H. Choper, Religion in the Public Schools: A Proposed Constitutional Standard, 47 MinN. L. Rev. 329 (1963); Jesse H. Choper, The Religion Clauses of the First Amendment: Reconciling the Conflict, 41 U. PITT. L. REV. 673 (1980); Jesse H. Choper, Defining "Religion" in the First Amendment, 1982 U. ILL. L. REv. 579; Jesse H. Choper, The Rise and Decline of the Constitutional Protection of Religious Liberty, 70 NEB. L. REV. 651 (1991). 
ultimately fails because his four principles lack a unifying theme. The result is that his position ultimately cannot withstand the tension it generates within itself. One manifestation of this tension is an interpretation of the Establishment Clause that both contradicts Choper's own assertions in the Free Exercise context and is implausible in its own right.

\section{II}

For each of the Religion Clauses, Choper offers one principle for use in evaluating laws whose purpose is to benefit or burden religion and another for secularly motivated laws that incidentally affect religious interests. Choper also provides clause-specific definitions of religion to act as gatekeeping mechanisms for each clause.

The first of Choper's principles pertaining to the application of the Free Exercise Clause is the "deliberate disadvantage principle." It applies to government actions that intentionally prejudice individuals based on their religious beliefs. Under this principle, such actions "should be held to violate the Free Exercise Clause unless the government demonstrates that the regulation is necessary to a compelling interest" (p. 41). If a regulation is found to violate this principle, Choper argues, it is invalid.

When a government regulation is not enacted with the intent of handicapping any individual or group on the basis of their religious beliefs, yet has the effect of doing so, Choper's second principle, the "burdensome effect principle," applies. According to this principle, the Free Exercise Clause requires that an exemption to generally applicable secular laws be granted so long as four conditions are satisfied: (1) the claimant has suffered cognizable injury; (2) the exemption does not violate the Establishment Clause or require the government to abandon its entire regulatory program; (3) the individual's beliefs are sincerely held and violation of those beliefs is thought to entail extratemporal consequences; and (4) the government cannot demonstrate that denial of the exemption is necessary to meet a compelling interest. When such an exemption is granted, the government should impose an alternative burden so long as one exists that does not conflict with the religious objector's beliefs (p. 54).

Choper realizes that "[t]he ultimate reach of the Free Exercise Clause can be expanded or limited at either the definitional or substantive steps of the process" (p. 63) and that there is a tension between the range of beliefs protected and the extent of the protection. For Choper, the appropriate source of limitation on the clauses is the definition of religion. Thus, he argues that "the very liberal substantive scope afforded by the burdensome effect principle calls for a definition of religion that is relatively compressed" (pp. 66-67). Choper's litmus test for religious beliefs is that such beliefs must be believed by the adherent to carry "extratemporal consequences" (implications reaching 
beyond this existence). This is what distinguishes religion from mere moral scruples. Choper defends this definition as having roots in the Founding (p. 79) and as flexible and capable of growth (p. 78). To the extent that it favors certain beliefs over others based on their content, he reminds us that "the dominant purpose of the Religion Clauses is to single out 'religion,' as opposed to other systems of belief." If a definition is to serve this goal, some minimum content is necessary (p. 78).

Choper's third and fourth principles pertain to interpretation of the Establishment Clause. The "intentional advantage principle" states that programs deliberately designed to favor religious interests should only be found to violate the Establishment Clause if they "pose a significant threat to religious liberty or if they are discriminatory" (p. 97). The "independent impact principle" holds that, absent a purpose to benefit religion, "government action that benefits religious interests and has no independent secular impact should be held to violate the Establishment Clause if the action poses a meaningful danger to religious liberty" (p. 160).

Choper intends that the term "religious" be interpreted more broadly in the Establishment Clause context than when dealing with the Free Exercise Clause. In particular, he argues that "ideological partisanship by government that would be commonly perceived as 'religious' should readily fall within the intentional advantage principle's definition of religion" (p. 104), as should any other instance in which the state "commit[s] its collective resources to persuade its people to believe in the validity of certain ideas" (p. 105). The Establishment Clause thus applies to anything that falls under the rubric of "narrow partisan ideologies" as opposed to "widely shared and basically noncontroversial public values" (p. 108).

Under Choper's principles, the lone restriction that the Establishment Clause places on government actions is that they must not pose a meaningful threat to religious liberty. ${ }^{3}$ According to Choper, government action may pose such a threat in two ways: (1) by "coercing or significantly influencing people either to violate their existing religious tenets, or to engage in religious activities or adopt religious beliefs when they would not otherwise do so" (p. 118) or (2) by "compelling people to afford financial support to their own religion or to that of others" (p. 118). The former raises an empirical question as to whether the government action would actually have the effect of encouraging or altering religious beliefs; the latter limits only the direct monetary subsidization of religion or religious institutions by government where full and independent secular value is not received. Choper points to government aid to parochial schools as an instance in which Establishment

3. Choper also injects the intentional advantage principle with a nondiscrimination requirement, but this does not go beyond the limitations mandated by the Equal Protection Clause and thus does not in any way add to the restrictions placed on government action. 
Clause jurisprudence (largely under the Lemon test ${ }^{4}$ ) has been unduly restrictive. He argues that, where assistance has a secular motivation (education) and yields full secular value (parochial schools receive no more dollars than would public schools to educate the same children), there is no violation of the Establishment Clause (pp. 176-79).

Choper realizes that this broad but weak conception of the Establishment Clause will insulate from constitutional scrutiny many government actions that "may reasonably be perceived as approval or endorsement of religion and may produce legitimate feelings of alienation and offense in a segment of the population" (p. 118). Such acts, however, "do not appear to alter anyone's actual political standing in any realistic sense" (p. 31). Hence, he argues, they should be permissible.

\section{III}

Choper's assertion that the fact that a government endorsement may engender feelings of alienation in members of outsider groups is insufficient to trigger Establishment Clause scrutiny (p. 31) is at odds with his recurrent contentions regarding the centrality of religion to individual identity (pp. 24, 74). More troublingly, Choper fails to explain why symbolic religious displays by the state are so much more palatable than symbolic racial displays.

In the landmark case of Plessy v. Ferguson, ${ }^{6}$ the Supreme Court stated that, if segregation caused harm to blacks by making them feel alienated or inferior, "it is not by reason of anything found in the act, but solely because the colored race chooses to put that construction upon it." In Brown v. Board of Education, ${ }^{8}$ the Court emphatically stated that the problem with segregation is that it "generates a feeling of inferiority as to [blacks'] status in the community," and that " [ $[t]$ he impact is greater when it has the sanction of law." "'10

Choper is of course sensitive to the possibility of a reductio ad Plessyum. $\mathrm{He}$ admits that "when government displays the symbols of the dominant religion ... the pain is not distributed evenly" (p. 101). ${ }^{11} \mathrm{He}$ insists, however, that the message sent to religious minorities is not as hurtful as that

4. See Lemon v. Kurtzman, 403 U.S. 602, 612-13 (1971).

5. Quoting Steven D. Smith, Symbols, Perceptions, and Doctrinal Illusions: Establishment Neutrality and the "No Endorsement" Test, 86 MICH. L. REV. 266, 307 (1987).

6. Plessy v. Ferguson, 163 U.S. 537 (1896).

7. Id. at 551 .

8. Brown v. Board of Education, 347 U.S. 483 (1954).

9. Id. at 494 .

10. Id. (quoting lower court's opinion).

11. Quoting Kenneth L. Karst, The First Amendment, the Politics of Religion and the Symbols of Government, 27 HARV. C.R.-C.L. L. REV. 503, 511 (1992). 
sent to racial minorities because "the overtones of racial prejudice" are lacking in the Establishment Clause setting (p. 102).

This effort to downplay religion's potential to cause feelings of exclusion clashes sharply with Choper's discussion of the "unique significance" of religious belief (p. 74). It is this unique significance, in fact, that triggers Choper's requirement that some individuals be granted exemptions, on free exercise grounds, from generally applicable laws. If religious beliefs are so central to many individual's identities as to require the extraordinary remedy of exemption, surely the "harm" or "offense" to a non-Christian of a government statement that "Christianity is our religion"12 cannot be dismissed as lightly as Choper contends. Other aspects of Choper's free exercise discussion support the parallel between race and religion. Contrary to his assertion that the religious context lacks the prejudicial overtones present in the context of race, for example, Choper claims that exemptions needs to be granted under the Free Exercise Clause precisely because religious beliefs have historically been the "object[] of public (and private) stereotyping, stigma, subordination, and persecution" (p. 42).

Choper also claims that race and religion can be distinguished in that our ultimate goal is that a person's race be irrelevant to government decisionmaking. By contrast, our heritage has approved of religious freedom and recognized that "'religion is a source of many good things"' (p. 102). ${ }^{13}$ It is unclear how this could possibly justify allowing government endorsement of a particular religion, however. Even conceding that religion is the source of many good things, it does not follow that the same is true of religious endorsement by government. It is precisely because of our commitment to religious pluralism that we have pursued a separationist policy. Religion was disestablished in colonial America in part because government endorsement was seen as a violation of conscience and because of fear that government entanglement would pollute religion. ${ }^{14}$

A further difficulty with Choper's broad but weak interpretation is that it renders any protection that the Establishment Clause confers redundant. ${ }^{15}$ Choper argues that it is both unnecessary (p. 103) and essentially impossible

12. Choper expressly defends the constitutionality of such a declaration (p. 157).

13. Quoting Gary J. Simson, Laws Intentionally Favoring Mainstream Religions: An Unhelpful Comparison to Race, 79 CORNELl L. REV. 514, 519 (1994).

14. See, e.g., JAMES MAdison, MEMORIAL AND REMONSTRANCE AGAinst REligious ASSESSMENTS (1785), reprinted in 8 THE PAPERS of JAMES MADISON 298, 301 (Robert A. Rutland et al. eds., 1973) ("[E]xperience witnesseth that ecclesiastical establishments, instead of maintaining the purity and efficacy of Religion, have had a contrary operation.").

15. It is a settled rule of construction that "every clause in a statute shall have effect." United States v. Landram, 118 U.S. 81, 85 (1886); see also THEODORE SEDGWICK, A TREATISE ON THE RULES WHICH GOVERN THE INTERPRETATION AND CONSTRUCTION OF STATUTORY AND CONSTITUTIONAL LAW 200 (JOhn N. Pomeroy annotator, New York, Baker, Voorhis \& Co. 2d ed. ann. 1874) ("II]n putting a construction upon any statute, every part shall be regarded; and it shall be so expounded, if practicable, as to give some effect to every part of it."). These rules are equally applicable to constitutional provisions. Id. at 19 ("The general rules of interpretation are the same, whether applied to statutes or Constitutions . ..."). 
(p. 107) to define religion as the term is appropriately understood in the Establishment Clause context. The only line that he believes can meaningfully and fruitfully be drawn is that between "narrow partisan ideologies" and "widely shared and basically noncontroversial public values" (p. 108). Because Choper places religion on a par with any other "narrow partisan ideolog[y],"16 anything that runs afoul of the Establishment Clause will also violate the free expression and association guarantees of the First Amendment. ${ }^{17}$

Choper's attempt to bring a comprehensive set of principles to Religion Clause jurisprudence is admirable but ultimately unsatisfying. Absent the guiding light of a unifying theme, Choper presents a set of principles that are in tension with one another. His failure to give an account of the special province of the Establishment Clause is only exacerbated by his exhortation of the importance of religion in the Free Exercise context. In the end, this failure puts at risk the very values that Choper endeavors to protect.

-Jason M. Freier

16. Choper explicitly states that "the state's attempt to convince its people of the 'ultimate truth' of the teachings of Dewey or Hegel ... . should be treated no differently for constitutional purposes from government's effort to persuade its citizens of the correctness of traditionally 'religious' systems of belief" (pp. 104-05).

17. Attempts to indoctrinate citizens have been held to invade "the sphere of intellect and spirit which it is the purpose of the First Amendment to our Constitution to reserve from all official control." West Va. State Bd. of Education v. Barnette, 319 U.S. 624, 642 (1943). 